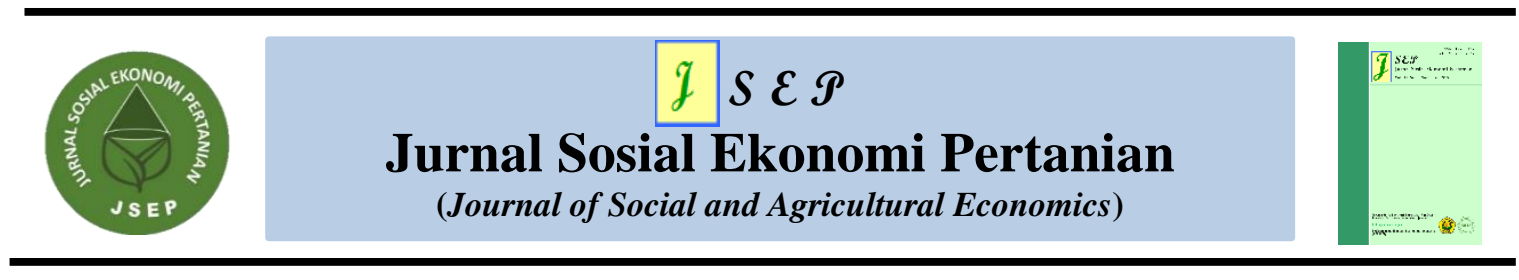

FAKTOR-FAKTOR YANG MEMPENGARUHI VOLUME EKSPOR KOPI INDONESIA KE JEPANG

\title{
FACTORS AFFECTING THE VOLUME OF INDONESIAN COFFEE EXPORT TO JAPAN
}

\author{
Ayu Sitanini ${ }^{1}$, Agus Sutanto ${ }^{2}$, Irene Kartika Eka Wijayanti ${ }^{2}$ \\ ${ }^{1}$ Magister Agribisnis Universitas Jenderal Soedirman \\ ${ }^{2}$ Jurusan Sosial Ekonomi/Agribisnis Fakultas Pertanian Universitas Jenderal Soedirman \\ email: sitanini87ayu@gmail.com
}

Naskah diterima: 22/07/2020 Naskah direvisi: 06/11/2020 Naskah diterbitkan: 30/11/2020

\begin{abstract}
The increase in coffee consumption in Japan is caused by several reasons, including changes in lifestyle in society due to westernization which introduced the habit of drinking coffee. Marketing that emphasizes instant coffee and roasted or ground coffee beans, a fast growing cafe or coffee shop. The product innovation process is increasingly developing so that Japanese people can enjoy coffee more easily. The research objective was to determine the factors that influence the volume of Indonesian coffee exports to Japan. The research method in this research uses quantitative methods. Type of data used is secondary data in the form of time series data from 1989 to 2018. The data sources were obtained from the directorate general of the United Nations and Commodities of Trade (UN Comtrade), World Bank. The analysis used multiple linear regression models through the ECM approach. The results showed that an increase in Japanese population, world tea prices and Indonesia Japan Economics Partnership (IJEPA) policies would increase the volume of Indonesian coffee exports to Japan. While Japanese coffee consumption, world coffee prices and inflation reduce the volume of Indonesian coffee exports to Japan. The increase in coffee production, Japanese GDP and the exchange rate did not increase or decrease the volume of coffee exports to Japan.
\end{abstract}

Keywords: coffee, exports, consumption, error correction model

\begin{abstract}
ABSTRAK
Peningkatan konsumsi kopi di Jepang disebabkan oleh beberapa alasan di antaranya adanya perubahan gaya hidup di masyarakat akibat westernisasi yang mengenalkan kebiasaan minum kopi. Pemasaran yang menekankan pada kopi instan dan biji kopi panggang atau kopi giling (roasted \& grind coffee), cafe atau kedai kopi yang berkembang pesat. Proses inovasi produk yang semakin berkembang sehingga masyarakat Jepang dapat menikmati kopi lebih mudah. Tujuan penelitian adalah mengetahui faktor faktor yang mempengaruhi volume ekspor kopi Indonesia ke Jepang. Metode penelitian dalam penelitian ini menggunakan metode kuantitatif. Jenis data yang digunakan adalah data sekunder dalam bentuk data deret waktu (time series) dari periode tahun 1989 hingga tahun 2018. Sumber data diperoleh berasal dari Direktorat Jendral Perkebunan (Ditjenbun), United Nations Commodity of Trade (UN Comtrade), World Bank. Analisis yang digunakan model regresi linier berganda melalui pendekatan ECM. Hasil penelitian menunjukan bahwa peningkatan jumlah penduduk Jepang, harga teh dunia dan kebijakan Indonesia Japan Economics Partnership (IJEPA) akan meningkatkan volume ekspor kopi Indonesia ke Jepang. Sedangkan konsumsi kopi Jepang, harga kopi dunia dan inflasi menurunkan volume ekspor kopi kopi Indonesia ke Jepang. Peningkatan produksi kopi, GDP Jepang dan kurs tidak meningkatkan atau menurunkan volume ekspor kopi ke Jepang.
\end{abstract}

Kata kunci: kopi, ekspor, konsumsi, error correction model

How to Cite: Sitanini, A., Sutanto, A., Wijayanti, I.K.E. (2020). Faktor-Faktor Yang Mempengaruhi Volume Ekspor Kopi Indonesia ke Jepang. JSEP: Jurnal Sosial Ekonomi Pertanian, 13(3): 253-263. 


\section{PENDAHULUAN}

Sejak tahun 2020 permintaan komoditas kopi mulai meningkat, baik lokal maupun internasional. Indonesia termasuk salah satu produsen kopi terbesar di dunia, dengan ekspor kopi Indonesia semakin meningkat setiap tahunnya. (Pusat_Data_dan_Sistem_Informasi_Pertanian, 2017) menyatakan bahwa produksi kopi di Indonesia periode tahun 1980 - 2017 yang berasal dari perkebunan rakyat (PR) didominasi oleh jenis kopi robusta (coffa canephora pierre) sebesar 81,87\% dan kopi arabika, 18,13\%. Asosiasi Eksportir Kopi Indonesia (AEKI) menyatakan kopi Indonesia sudah teruji standar kualitasnya dan diterima oleh seluruh negara di dunia karena sudah mendapatkan pengakuan dan sertifikat dari ICO (International Coffee Organization). Hal ini semakin mendukung ekspor kopi Indonesia dan mampu meningkatkan daya saing dengan negara eksportir lainnya.

Ekspor kopi Indonesia telah menjangkau kebeberapa negara di dunia. Pada tahun 2016 Amerika Serikat merupakan negara tujuan utama ekspor kopi Indonesia dengan share ekspor mencapai 26,77\% setara dengan nilai ekspor sebesar USD 269,94 juta. Diikuti oleh Jerman dengan share ekspor sekitar 8,94\% atau senilai USD 90,19 juta, Jepang total 8,58\% (USD 86,511 juta) dan Malaysia 7,08\% (USD 71,43 juta), (Pusat_Data_dan_Sistem_Informasi_Pertanian, 2017). Jepang terkenal dengan konsumsi teh hijau, namun permintaan kopi di Jepang semakin bertumbuh pesat. Berdasarkan data statistik International Coffee Organization (ICO) menunjukkan bahwa Jepang termasuk salah satu negara konsumen kopi terbesar di dunia, dari tahun 2007 2017 permintaan impor kopi (termasuk kopi instan) di Jepang meningkat 1,5\% per tahun, atau tumbuh sebesar 2,3\% di tahun 2017. Berdasarkan sumber kementrian perdagangan dalam Laporan Informasi Intelijent Bisnis (2018), Terdapat enam negara utama pemasok kopi, jenis biji kopi hijau dan kopi regular di Jepang yaitu Brazil, Kolombia, Vietnam, Guatemala, Ethiopia dan Indonesia. Berdasar nilai impor, impor kopi Jepang mencapai US\$ 1,43 miliar tahun 2017, meningkat 1,2\% dari tahun sebelumnya. Nilai impor kopi yang berasal dari Brazil sebesar US\$ 385,5 juta (turun $12,2 \%$ year-on-year), diikuti oleh Kolombia US\$277,9 juta (naik 17,7\%), Vietnam US\$ 200,5 juta (naik 10,8\%), Guatemala US\$ 128,6 juta (turun 15,9\%), Ethiopia US\$ 96,1 juta (naik 50,4\%) dan Indonesia US\$ 93,3 juta (naik 4,6\%).

Peningkatan konsumsi kopi di Jepang disebabkan oleh beberapa alasan di antaranya adanya perubahan gaya hidup di masyarakat akibat westernisasi yang mengenalkan kebiasaan minum kopi. Pemasaran yang menekankan pada kopi instan dan biji kopi panggang atau kopi giling (roasted \& grind coffee), cafe atau kedai kopi yang berkembang pesat. Proses inovasi produk yang semakin berkembang sehingga masyarakat Jepang dapat menikmati kopi lebih mudah. Konsumsi kopi negara Jepang berfluktuatif cenderung meningkat, pada tahun 2015 sebesar $461.700 \mathrm{~kg}$, tahun 2016 sebesar 472.320kg dan tahun 2017 sebesar 472.320kg. Impor kopi di Jepang didominasi oleh biji kopi hijau dengan pangsa sebesar $86,7 \%$ sementara impor kopi reguler dan kopi instan memiliki pangsa yang hampir sama yaitu 6,5\% dan 6,8\% berturut-turut di tahun 2017. Berbagai jenis kopi dengan kualitas prima diimpor seperti jenis kopi kualitas prima Kona dari Hawaii, Blue Mountain dari Jamaica, kopi Brazil atau kopi Mandailing dan Kopi Toraja dari Indonesia.

Permintaan ekspor kopi berfluktuasi baik ke pasar luar negeri termasuk ke Jepang disebabkan oleh faktor-faktor yang berpengaruh terhadap permintaan maupun penawaran. Penelitian terdahulu menunjukkan faktor yang mempengaruhi ekspor adalah GDP per kapita, nilai tukar riil dan jarak ekonomi di pasar ASEAN (Zuhdi, 2016). GDP 
riil, kurs, harga kopi internasional, harga kopi domestik faktor penting dalam ekpor kopi Indonesia (Ramdhani, 2018). Produksi kopi Indonesia, harga kopi Indonesia ke Malaysia dan nilsi tukar rupiah terhadap dollar Amerika berpengaruh terhadap volume ekspor kopi Indonesia ke Malaysia (Setiawan \& Sugiarti, 2016). Ekspor kopi Indonesia ke Amerika dengan metode OLS (Ordinary Least Square) periode tahun 1981 - 2016, dipengaruhi oleh produksi, inflasi dan kurs (Kartini, 2018). Perbedaan penelitian ini dari penelitian sebelumnya, penelitian ini memberikan gambaran kondisi, potensi komoditi kopi dengan negara tujuan Jepang dan melihat dari sisi faktor permintaan maupun penawaran. Indonesia memiliki beberapa keunggulan yang dapat menjadi peluang untuk dapat bersaing di Jepang dan kopi di negara Jepang memiliki potensi besar bagi Indonesia untuk mengembangkan atau meningkatkan ekspor kopi. Penelitian bertujuan, mengkaji dan menganalisis mengenai faktor - faktor yang mempengaruhi volume kopi Indonesia ke Jepang. Kajian ini di harapkan mampu memberikan pedoman untuk meningkatkan ekspor kopi Indonesia ke Jepang, mengingat persaingan dalam industri kopi yang semakin kompetitif dimasa mendatang.

\section{METODE PENELITIAN}

Penelitian ini menggunakan metode kuantitatif. Menurut (Sugiyono, 2008) metode kuantitatif yaitu metode penelitian yang berlandaskan pada filsafat positivisme digunakan untuk meneliti populasi atau sampel tertentu, pengumpulan data menggunakan instrumen penelitian, analisis data bersifat kuantitatif/statistik, dengan tujuan untuk menguji hipotesis yang telah ditetapkan.

Jenis data yang digunakan dalam penelitian ini adalah data sekunder dalam bentuk data deret waktu (time series) dari periode tahun 1989 sampai dengan tahun 2018. Sumber data sekunder merupakan sumber yang tidak langsung memberikan data kepada pengumpul data, misalnya lewat orang lain atau lewat dokumen (Sugiyono, 2017). Sumber data diperoleh berasal dari Direktorat Jendral Perkebunan (Ditjenbun), United Nations Commodity of Trade (UN Comtrade), World Bank dan instansi lainnya. Serta menggunakan referensi lain seperti buku, jurnal dan artikel.

\section{Analisis Faktor-Faktor Yang Mempengaruhi Volume Ekspor: Error Correction Model (ECM).}

Menentukan model regresi linier berganda melalui pendekatan ECM, terdapat beberapa asumsi yang harus di penuhi sebagai berikut (Gujarati, 2004), yaitu:

\section{a. Deteksi Stasioneritas: Uji Akar Unit (Unit Root Test)}

a) Keberadaan unit root problem bisa terlihat dengan cara membandingkan nilai tstatistiks table (t-McKinnon Critical Values) hasil regresi dengan nilai tes Augmented Dickey Fuller (ADF). Apabila t-statistiks ADF lebih kecil dari tstatistiks table dengan taraf nyata, maka data mengandung akar unit atau data tidak stasioner (terima $H_{o}$ ).

b) $\boldsymbol{H}_{\boldsymbol{o}}=$ data tidak stasioner (mengandung akar unit)

c) $\boldsymbol{H}_{\mathbf{1}}=$ data stasioner (tidak mengandung akar unit)

d) Penolakan hipotesis nol menunjukkan data yang dianalisis adalah stasioner. Variabel dikatakan tidak stasioner, jika terdapat hubungan antara variabel tertentu dengan waktu atau trend.

\section{b. Uji Derajat Integrasi}

Uji derajat integrasi dilakukan apabila data tidak stasioner pada waktu uji kestasioneran. 
Granger dan Newbold dalam (Nachrowi, 2006), berpendapat bahwa regresi yang menggunakan data tersebut biasanya mempunyai nilai $R^{2}$ yang relatif tinggi namun memiliki statistik Durbin-Watson yang rendah. Ini memberi indikasi bahwa regresi yang dihasilkan adalah regresi lancung. Secara umum apabila suatu data memerlukan deferensiasi sampai ke $d$ supaya stasioner, maka dapat dinyatakan sebagai I $(d)$.

\section{c. Uji Kointegrasi}

Uji kointegrasi merupakan kelanjutan dari uji akar unit dan uji derajat integrasi. Uji kointegrasi dimaksudkan untuk menguji apakah residual regresi yang dihasilkan stasioner atau tidak (Roger \& Engler, 2008).

Ada dua cara pengujian kointegrasi antara lain:

a) Uji Eangle - Granger (Augmented Engle - Granger)

Uji Engle-Granger dilakukan dengan memanfaatkan uji DF-ADF. Adapun tahapannya adalah

1) Estimasi model regresi

2) Hitung residualnya

3) Jika residualnya stasioner, berarti regresi tersebut merupakan regresi kointegrasi

b) Uji kointegrasi Durbin-Watson (Cointegrating Regression Durbin-Watson)

Tahapan pengujiannya sebagai berikut:

1) Hitung statistik Durbin-Watson $(d)$, dengan $d=2(1-\rho)$ pada saat $\rho$ bernilai 1 , maka $d$ bernilai 0 . Oleh karena itu hipotesis yang digunakan:

$$
\begin{aligned}
& H_{0}: d=0 \\
& H_{0}: d \neq 0
\end{aligned}
$$

2) Bandingkan nilai $d$ hitung dengan $d$ tabel.

Jika d hitung lebih besar dari d table ( $\left.d_{\text {hitung }}>d_{\text {tabel }}\right)$, dengan $d_{\text {tabel }}$ adalah nilai diperoleh dari tabel Durbin Watson, dengan $\alpha=0,05$ maka hipotesis $H_{0}$ ditolak artinya $u_{t}$ staisoner dan terjadi kointegrasi antar peubah.

Pembentukan model ECM diawali dengan pembentukan model persamaan jangka panjang sesuai teori yang berlaku. Persamaan regresi yang akan diujikan pada penelitian ini adalah sebagai berikut:

$$
\begin{aligned}
V E_{t}= & \alpha_{0}+\alpha_{1} P R O_{t}+\alpha_{2} \text { GDPJPN }_{t}+\alpha_{3} P O P_{t}+\alpha_{4} K K J P G_{t}+\alpha_{5} \text { Kurs }_{t} \\
& +\alpha_{6} \text { HKD }_{t}+\alpha_{7} \text { HTD }_{t}+\alpha_{8} \text { Inf }_{t}+\alpha_{9} D_{t}+\text { et }
\end{aligned}
$$

Keterangan:

$V E_{t}$

$P R O_{t} \quad:$ Produksi Kopi Indonesia tahun ke - $\mathrm{t}$ (ton)

$G_{P D P P N} \quad:$ GDP Negara Jepang ahun ke - $\mathrm{t}(\mathrm{US} \$ / \mathrm{th})$

$P O P_{t} \quad:$ Jumlah penduduk negara Jepang (jiwa/ th)

$K K J P G_{t} \quad:$ Konsumsi Kopi Jepang (ton / tahun)

Kurs $_{t} \quad$ : Nilai tukar Rupiah tahun terhadap Yen tahu ke $-\mathrm{t}(\mathrm{Rp} / \mathrm{Japanese}$

Yen)

$H K D_{t} \quad$ : Harga Kopi Dunia (US\$)

$H T D_{t} \quad$ : Harga Teh Dunia (US\$)

Inf $f_{t} \quad$ : Inflasi (\%)

$D_{t} \quad$ : Dummy IJEPA tahun ke-t $(\mathrm{D}=1=$ setelah penerapan IJEPA. D $=0=$ sebelum penerapan IJEPA)

$e_{t} \quad:$ Standar Error tahun ke - $\mathrm{t}$ 


$$
\begin{array}{ll}
\alpha_{0} & : \text { Konstanta } \\
\alpha_{1}-\alpha_{9} & : \text { Koefisien dugaan dari variabel independent }
\end{array}
$$

Hipotesis faktor - faktor yang mempengaruhi ekspor kopi Indoensia di Jepang

$\mathrm{X}_{1}$ : Produksi kopi Indonesia berpengaruh positif terhadap volume ekspor kopi Indonesia ke Jepang.

$\mathrm{X}_{2}$ : GDP per kapita penduduk Jepang berpengaruh positif terhadap volume ekspor kopi ke Jepang

$\mathrm{X}_{3}$ : Jumlah penduduk negara Jepang berpengaruh positif terhadap volume ekspor kopi Indonesia ke Jepang

$\mathrm{X}_{4}$ : Konsumsi kopi negara Jepang berpengaruh positif terhadap volume ekspor kopi Indonesia ke Jepang.

$\mathrm{X}_{5}$ : Nilai tukar rupiah berpengaruh negatif terhadap volume ekspor kopi Indonesia ke Jepang

$\mathrm{X}_{6}$ : Harga kopi dunia berpengaruh negatif terhadap volume ekspor kopi Indonesia ke Jepang

$\mathrm{X}_{7}$ : Harga Teh Dunia berpengaruh positif terhadap volume ekspor kopi Indonesia ke Jepang

$\mathrm{X}_{8}$ : Inflasi negara Indonesia, inflasi berpengaruh negatif terhadap volume ekspor kopi Indonesia ke Jepang

$\mathrm{X}_{9}$ : Perjanjian kerjasama IJEPA berhubungan positif terhadap volume ekspor kopi Indonesia ke Jepang. Ketika terjadi kerjasama IJEPA ekspor kopi Indonesia ke Jepang akan meningkat.

ECM memiliki ciri khas dengan adanya unsur ECT (Error Correction Term). ECT merupakan residual yang timbul dalam metode ECM. Menurut model ini, harus terus diingat bahwa perbaikan koefisien error selalu diekspektasikan sebagai negatif dan secara statistik, nilai ECM adalah signifikan maka ECM valid (Gujarati, 2004). Guna mengetahui hubungan secara empiris antara Volume Ekspor Kopi Indonesia dengan variabel tak terikat, tidak dapat dideteksi keseimbangannya secara langsung. Akan tetapi dapat diestimasikan dalam persamaan jangka pendek dengan memasukkan unsur kelambanan.

Persamaan model jangka pendek ditunjukkan sebagai berikut:

$$
\begin{aligned}
\Delta L n V E_{t}= & \beta_{0}+\beta_{1} \Delta P R O_{t}+\beta_{2} \Delta G D P J P N_{t}+\beta_{3} \Delta P O P_{t}+\beta_{4} \Delta K K J P G_{t}+ \\
& \beta_{5} \Delta K \operatorname{Kurs}_{t}+\beta_{6} \Delta H K D_{t}+\beta_{7} \Delta N H T D_{t}+\beta_{8} \Delta I N F_{t}+E C T_{t-1}+\mu_{t}
\end{aligned}
$$

Uji asumsi klasik meliputi uji Multikolinearitas, Heteroskedastisitas, dan Autokorelasi bertujuan untuk mengetahui apakah model regresi yang diestimasi bersifat Best Linear Unbiased Estimator (BLUE).

\section{HASIL DAN PEMBAHASAN}

\section{A. Faktor - Faktor yang Berpengaruh terhadap Volume Ekpor Kopi Indonesia di Pasar Jepang}

Variabel dependen dalam model ini adalah volume ekspor yang diduga dapat dipengaruhi dan dijelaskan oleh variabel independent seperti produksi kopi Indonesia, GDP negara Jepang, jumlah penduduk negara Jepang, konsumsi kopi Jepang, kurs rupiah, harga kopi dunia, harga teh dunia, inflasi dan dummy perjanjian IJEPA. 
Tahapan dalam analisis Error Correction Model sebagai berikut:

\section{Uji Stasioneritas}

\section{Uji Akar Unit (Unit Root Test)}

Langkah awal dalam pengujian ECM yaitu melalui pengujian unit root test dengan menggunakan uji ADF (Augmented Dicky Fuller Test). Pengujian ini dilakukan untuk mengetahui kestasioneran data. Syarat data stasioner adalah apabila nilai probabilitas dari masing-masing variabel lebih kecil dari nilai taraf nyata $(\alpha=10 \%)$ atau nilai $t$-statistik ADF dari masing-masing variabel lebih kecil dibandingkan nilai kritis Mac Kinnon pada tingkat kepercayaan sampai 90 persen $(\alpha=10 \%)$.

\section{Hasil Uji Unit Root Pada Tingkat Level}

Tabel 1. Hasil uji unit root pada tingkat level

\begin{tabular}{lccccc}
\hline Method & & & & Statistic & Prob.*** \\
\hline ADF - Fisher Chi-square & & & & 32.0065 & 0.0432 \\
ADF - Choi Z-stat & Prob. & Lag & Max Lag & Obs & Keputusan \\
\hline \hline \multicolumn{1}{c}{ Series } & 0.6719 & 0 & 5 & 26 & tidak stasioner \\
\hline Volume_Ekspor & 0.5232 & 0 & 5 & 26 & tidak stasioner \\
Produksi & 0.0980 & 0 & 5 & 26 & tidak stasioner \\
GDP_Jepang & 0.7718 & 3 & 5 & 23 & tidak stasioner \\
Populasi_Jepang & 0.6049 & 0 & 5 & 26 & tidak stasioner \\
Konsumsi_Kopi Jepang & 0.8369 & 0 & 5 & 26 & tidak stasioner \\
Nilai_Riil_Kurs & 0.2329 & 0 & 5 & 26 & tidak stasioner \\
Harga_Kopi_Dunia & 0.0112 & 0 & 5 & 26 & stasioner \\
Harga_Teh_Dunia & 0.0039 & 0 & 5 & 26 & stasioner \\
Inflation_Ind & 0.8244 & 0 & 5 & 26 & tidak stasioner \\
Dummy_IJEPA & & & & & \\
\hline \hline
\end{tabular}

Sumber: Output Eviews, 2020

Dari uji root test tingkat level, menunjukan bahwa hanya ada dua variabel yang stasioner yaitu harga teh dunia dan inflasi Indonesia, sehingga dilanjutkan dengan uji tingkat first difference. Dari hasil uji tingkat first diference, masih ada satu yang tidak stasioner sehingga dilanjutkan sampai tingkat second diference. Pada tingkat second difference semua variable independen, stasioner.

\section{Uji Integrasi}

Tabel 2. Hasil uji unit root pada tingkat first difference dan second difference

\begin{tabular}{|c|c|c|c|c|}
\hline Method & Statistic & Prob.** & Statistic & Prob.** \\
\hline ADF - Fisher Chi-square & 158.536 & 0,0000 & $\begin{array}{r}235.656 \\
-13.5438\end{array}$ & 0,0000 \\
\hline ADF - Choi Z-stat & -9.44667 & 0,0000 & 0,0000 & 0,0000 \\
\hline Series & Prob. & Keputusan & Prob. & Keputusan \\
\hline Volume_Ekspor & 0.0000 & Stasioner & 0.0000 & Stasioner \\
\hline Produksi & 0.0001 & Stasioner & 0.0000 & Stasioner \\
\hline GDP_Jepang & 0.0099 & Stasioner & 0.0014 & Stasioner \\
\hline Populasi_Jepang & 0.9877 & Tidak Stasioner & 0.0001 & Stasioner \\
\hline Konsumsi_Kopi Jepang & 0.0011 & Stasioner & 0.0000 & Stasioner \\
\hline Nilai_Riil_Kurs & 0.0005 & Stasioner & 0.0000 & Stasioner \\
\hline Harga_Kopi_Dunia & 0.0001 & Stasioner & 0.0000 & Stasioner \\
\hline Harga_Teh_Dunia & 0.0000 & Stasioner & 0.0000 & Stasioner \\
\hline Inflation__Ind & 0.0000 & Stasioner & 0.0002 & Stasioner \\
\hline Dummy_IJEPA & 0.0005 & Stasioner & 0.0000 & Stasioner \\
\hline
\end{tabular}

Sumber: Output Eviews diolah, 2020 
Dari unit root test tingkat second difference, menunjukkan seluruh variabel independen sudah stasioner. Sehingga dapat disimpulkan bahwa model ini telah memenuhi uji stasioneritas. Uji selanjutnya adalah melakukan uji ko-integrasi. Uji kointegrasi dilakukan dengan tujuan untuk mengetahui hubungan jangka panjang antar variabel. Syarat yang dibutuhkan untuk menunjukkan bahwa diantara variabel-variabel yang diteliti berkointegrasi adalah dengan melihat perilaku residual dari regresi persamaan yang digunakan, dimana residualnya harus stasioner.

\section{Uji Kointegrasi (Cointegration Approach)}

Hasil uji stasioneritas terhadap residual regresinya dapat dilihat pada Table 3.

Tabel 3. Hasil uji unit root terhadap residual persamaan regresi

Null Hypothesis: RES has a unit root

Exogenous: Constant

Lag Length: 1 (Automatic - based on SIC, maxlag=6)

\begin{tabular}{lccc}
\hline & & t-Statistic & Prob. $^{*}$ \\
\hline \hline \multicolumn{2}{l}{ Augmented Dickey-Fuller test statistic } & -5.0315 & 0.0004 \\
\hline Test critical values: & $1 \%$ level & -3.72407 & \\
& $5 \%$ level & -2.98623 & \\
& $10 \%$ level & -2.6326 & \\
\hline \hline
\end{tabular}

Sumber: analisis data sekunder

Berdasar hasil uji kointegrasi pada Tabel 3. ditunjukkan bahwa residual dari persamaan regresi stasioner pada tahap second different dalam selang kepercayaan 5\% $(\alpha=0,05)$. Hal ini dapat dilihat dari nilai statistik ADF (- 5.0315) yang lebih kecil dari nilai kritis ADF pada $\alpha=5 \%(-2.98623)$ atau dapat juga di lihat dari nilai probabilitas (F-statistic) yang lebih kecil dari alpha 0.05 yaitu 0,0004. Artinya bahwa variabel dependent (volume ekspor) dan variabel independent (produksi kopi Indonesia, GDP per kapita negara Jepang, jumlah penduduk Jepang, konsumsi kopi negara Jepang, nilai tukar rupiah, harga kopi dunia, harga teh dunia, inflasi negara Indonesia, dan IJEPA) saling berkointegrasi, sehingga diperoleh persamaan.

Berdasarkan hasil estimasi kointegrasi (jangka panjang) dengan tingkat kepercayaan $95 \%$ variabel populasi penduduk Jepang, harga teh dunia dan dummy kebijakan IJEPA berpengaruh positif sedangkan konsumsi kopi Jepang, dan harga kopi dunia, berpengaruh negatif terhadap ekspor kopi ke Jepang. Produksi kopi Indonesia, GDP per kapita Jepang, jumlah penduduk Jepang dan inflasi Indonesia tidak berpengaruh terhadap ekspor kopi Indonesia ke Jepang.

$$
V E_{t}=\begin{gathered}
1.22 \mathrm{E}+10+6.70773 \mathrm{POP}_{t}-220.8651 \mathrm{KONS}_{t}-18070.21 \mathrm{HKD}_{t}+ \\
\text { 363.205 HTD }+ \text { 123.50.624 DIJEPA } A_{t} .
\end{gathered}
$$

\section{Error Corection Model (ECM)}

Berdasarkan hasil analisis kointegrasi (jangka panjang), menunjukan bahwa perubahan pada volume ekspor kopi, produksi kopi, GDP Jepang Populasi Jepang, Konsumsi kopi Jepang, Nilai tukar rupiah terhadap Yen, harga kopi dunia, harga teh dunia, inflansi dan dummy variabel kebijakan IJEPE memiliki hubungan kointegrasi. Sehingga untuk selanjutnya dilakukan estimasi jangka pendek dengan model ECM. 
ECM digunakan untuk melihat keterkaitan atau pengaruh variabel tak terikat terhadap variabel terikat dalam jangka pendek. Dalam jangka pendek ada kemungkinan terjadi ketidakseimbangan (disekuilibrium). Karena adanya ketidakseimbangan maka diperlukan adanya koreksi dengan model koreksi kesalahan (Error Corection Model). Persamaan yang digunakan merupakan persamaan regresi menggunakan variabelvariabel yang sebelumnya sudah distasionerkan kemudian ditambah variabel error (-1) yang merupakan residual tahun sebelumnya (Rexsi dan Haryadi, 2017). Hasil regresi jangka pendek dengan mengunakan Error Correction Model disajikan pada Tabel 4.

Tabel 4. Estimasi Jangka Pendek Model ECM

\begin{tabular}{lrrrr}
\hline \hline \multicolumn{1}{c}{ Variabel } & Koefisien & Std. Error & Nilai t-hitung & Prob. $|\mathrm{t}|$ \\
\hline \hline C & $441.456,10$ & $958.924,20$ & 0,460366 & 0,6519 \\
D(PRODUKSI) & $-19.551,80$ & $22.611,23$ & $-0,864692$ & 0,4008 \\
D(GDP_PER_CAPITA) & 224,26 & 233,39 & 0,960849 & 0,3519 \\
D(POPULASI_NEGARA_JEPANG) & 7,09 & 2,76 & 2,56737 & 0,0214 \\
D(CONSUMPTION) & $-266,72$ & 65,82 & $-4,052468$ & 0,0010 \\
D(KURS) & 12,78 & 6,03 & 2,119263 & 0,0512 \\
D(HARGA_KOPI_DUNIA) & -185.770 & 3561.05 & $-5,216718$ & 0,0001 \\
D(HARGA_TEH_DUNIA) & 269,55 & 116,90 & 2,305593 & 0,0358 \\
D(INFLATION) & -183.522 & $63.120,12$ & $-2,907501$ & 0,0108 \\
D(DUMMY_IJEPA) & $11.270 .238,00$ & 4.759 .594 & 2,367899 & 0,0318 \\
ECT(-1) & $-0,1461$ & 0.24 & $-6,04276$ & 0,0000 \\
\hline \hline R-squared & 0,837585 & Mean dependent var & & $-1.171 .014,00$ \\
Adjusted R-squared & 0,729308 & S.D. dependent var & & $6.574 .899,00$ \\
F-statistic & 7,735573 & Durbin-Watson stat & & 2,18 \\
Prob(F-statistic) & 0,000264 & & & \\
\hline \hline
\end{tabular}

Sumber : Analisis data primer, 2020

Hasil estimasi jangka pendek variabel produksi tidak signifikan dengan nilai koefisien $-19,551$ dan nilai probability sebesar 0,4008 artinya setiap kenaikan atau penurunan produksi kopi Indonesia tidak mempengaruhi kenaikan atau penurunan volume ekspor kopi Indonesia ke Jepang. Rata-rata impor Jepang pada kopi Indonesia sebesar 40 ribu ton, sedangkan produksi kopi Indonesia mencapai hampi 700 ribu ton. Hal inilah yang menyebabkan produksi kopi Indonesia tidak signifikan terhadap volume ekspor kopi ke Jepang. Penelitian (Ginting \& Kartiasih, 2019) menyatakan bahwa produksi kopi Indonesia tidak berpengaruh nyata terhadap ekspor kopi Indonesia ke Negara Asean.

GDP per kapita Jepang tidak berpengaruh nyata tehadap volume ekspor kopi Indonesia ke Jepang. Kondisi ini terjadi karena kecil nilai impor kopi Indonesia dibandingkan dengan besarnya nilai GDP per kapita Jepang. GDP Jepang sebesar US\$ 4,971 triliun sedangkan nilai impor kopi Indonesia hanya sebesar 93.3 juta USD (Laporan Informasi Intelijen Bisnis, 2018). Populasi Negara Jepang berpengaruh nyata terhadap ekspor kopi Indonesia ke Jepang, dengan nilai koefisen regresi 7,09, setiap kenaikan satu penduduk Jepang akan meningkatkan impor kopi Indonesia, sebesar 0,007 kg. Penelitian (Reyandi et al., 2018), menyatakan pengaruh GDP Amerika terhadap ekspor kopi Indonesia ke Amerika, berpengaruh positif.

Peningkatan konsumsi kopi Jepang akan menurunkan ekspor kopi Indonesia ke Jepang. Secara teori, hal ini tentunya menyalahi kaidah ekonomi, tetapi hal ini dapat saja terjadi karena kopi yang berasal dari Indonesia sebagaian besar bukan kopi yang 
terbaik jika dibandingkan dengan kopi yang berasal dari Brasil. Jadi kemungkinan konsumsi kopi masyarakat Jepang lebih memilih kopi yang lebih berkualitas.

Nilai tukar rupiah terhadap yen berpengaruh positip terhadap volume ekspor Indonesia sebesar 12,78, hal ini menunjukan jika nilai tukar rupiah terhadap yen menguat maka volume ekspor ke Jepang meningkat. Dapat diartikan bahwa setiap yen yang diperoleh dari ekspor kopi akan memperoleh rupiah yang lebih banyak dan harga kopi di Jepang lebih murah. Setiap kenaikan nilai tukar yen terhadap rupiah sebesar satu yen, akan meningkatkan volume ekspor kopi ke Jepang sebesar 12,78 kg. (Ginting \& Kartiasih, 2019), menyatakan variabel nilai tukar riil negara tujuan ekspor kopi berpengaruh negatif dan signifikan terhadap volume ekspor komoditi kopi Indonesia ke negara tersebut. (Widayanti et al., 2009), nilai kurs rupiah terhadap dolar Amerika berpengaruh nyata dan positif terhadap volume ekspor kopi Indonesia.

Pergerakan impor kopi Jepang terhadap terhadap kenaikan harga kopi dunia mempunyai respon negatif yang tinggi. Dari Tabel 4. terlihat bahwa koefisien harga kopi dunia sebesar -185.770, setiap kenaikan harga kopi dunia sebesar 1 dollar akan menurunkan permintaan kopi Indonesia sebesar $185.770 \mathrm{~kg}$. Pada umumnya kenaikan harga kopi dunia disebabkan oleh adanya penawaran yang menurun. (Widayanti et al., 2009), harga kopi di pasar internasional tinggi terjadi karena jumlah penawarannya berkurang, akibat adanya kegagalan panen di negara Brasil yang merupakan pemasok kopi terbesar di pasar dunia (28\% dari total ekspor kopi dunia). Indonesia tidak dapat mengganti posisi Brasil dipasar dunia (walaupun Indonesia merupakan negara produsen terbesar ketiga setelah Brasil dan Columbia) pada saat negara tersebut mengalami kegagalan panen dikarenakan kualitas kopi Indonesia yang masih rendah belum dapat menyamai kualitas kopi dari negara Brasil yang terkenal dengan kopi berkualitas tinggi yang sangat diminati konsumen luar negeri. Hasil penelitian (Anggraini, 2006), variabel harga kopi dunia berpengaruh signifikan terhadap volume ekspor kopi Indonesia ke Amerika.

Di Jepang teh merupakan barang substitusi dari kopi, hal ini ditunjukkan dengan koefisen regresi harga teh dunia yang positif. Koefisen regresi harga teh dunia sebesar 269,55, yang berarti setiap kenaikan harga teh dunia sebesar 1 US\$ akan menaikan volume ekspor kopi Indonesia sebesar $269,55 \mathrm{~kg}$. Hal ini terkait dengan pengaruh kenaikan harga kopi dunia yang menyebabkan ekspor kopi ke Jepang menurun. (Widayanti et al., 2009), harga teh (sebagai komoditi subsitusi kopi) menunjukkan pengaruh yang nyata terhadap kuantitas ekspor kopi Indonesia. Pengaruh harga teh ini ditunjukkan oleh koefisien fungsi yang positif, hal ini berarti bahwa komoditi teh bersifat substitusi terhadap komoditi kopi yaitu peningkatan harga komoditi teh menyebabkan konsumen beralih lebih banyak mengkonsumsi kopi.

Inflasi berpengaruh negatif terhadap volume ekspor kopi Indonesia ke Jepang, dengan koefisien regresi sebesar -183.522. Hal ini menunjukan bahwa setiap kenaikan inflasi sebesar 1 persen, akan menurunkan volume ekspor kopi sebesar $183.522 \mathrm{~kg}$. Inflasi menyebabkan harga-harga barang di dalam negeri naik, termasuk harga kopi juga ikut naik. Kenaikan harga kopi akan memicu berkurangnya ekspor kopi ke Jepang.

IJEPA adalah perjanjian perdagangan bilateral antara Indonesia dan Jepang yang bertujuan untuk meningkatkan daya tarik ekspor dan impor, investasi baik di Indonesia maupun Jepang. Perjanjian ini disusun agar menghasilkan manfaat bagi kedua negara secara fair, seimbang dan terukur melalui liberalisasi akses pasar, fasilitasi dan kerjasama melalui pengembangan kapasitas untuk sektor-sektor industri prioritas (kemenkeu.go.id/ diakses tgl 29 November 2016). Hasil analisis regresi menunjukan 
bahwa varibel IJEPA berpengaruh nyata dan mempunyai arah yang positip. Hal ini menunjukan bahwa adanya IJEPA dapat meningkatkan jumlah volume kopi yang di ekspor ke Jepang yang cukup besar, yaitu sebesar 11.270.238 kg.

ECT $(-1)$ dengan nilai koefisien $(-1,4366)$ mempunyai arti bahawa apabila terdapat ketidakseimbangan masalalu sebesar $100 \%$, maka perubahan volume ekspor akan menyesuaikan diri dengan menurun sebesar 1,43. Dapat diinterprestasikan bahwa volume ekspor membutuhkan waktu 1 tahun untuk mencapai keseimbangan. Hasil pengujian terhadap penyimpangan asumsi klasik, hanya terdapat multikolinearitas antara GDP dengan produksi kopi Indonesia. Sedangkan untuk heteroskedasitas dan otokorelasi tidak menyebabkan penyimpangan asumsi klasik.

\section{KESIMPULAN}

Peningkatan produksi kopi Indonesia dan GDP Negara Jepang, tidak meningkatkan atau menurunkan volume ekspor. Peningkatan konsumsi kopi Jepang, harga kopi dunia, dan inflasi akan menurunkan volume ekspor kopi Indonesia, sedangkan peningkatan populasi penduduk Jepang, nilai tukar rupiah terhadap yen (KURS riil), harga teh dunia dan IJEPA akan meningkatkan volume ekspor kopi Indonesia ke Jepang. Penelitian ini merekomendasikan bahwa perlunya mempererat hubungan bilateral Indonesia dan Jepang. Hubungan bilateral dapat lebih diaktifkan dengan memperkenalkan kopi-kopi yang memiliki cita rasa khas.

\section{DAFTAR PUSTAKA}

Anggraini, D. (2006). Faktor-faktor yang Mempengaruhi Permintaan Ekspor Kopi Indonesia dari Amerika Serikat. Universitas Diponegoro.

Ginting, C. P., \& Kartiasih, F. (2019). Analisis Ekspor Kopi Indonesia Ke NegaraNegara Asean. Jurnal Ilmiah Ekonomi Dan Bisnis, 16(2), 143-157.

Gujarati, D. (2004). Basics Econometrics (4th ed.). The McGraw Hill Companies.

Kartini, W. (2018). Analisis Faktor Yang Mempengaruhi Eksporkopi Indonesia Ke Amerika Serikat. Universitas Muhammadiyah Yogyakarta.

Nachrowi, N. D. (2006). Pendekatan Populer dan Praktis Ekonometrika untuk Analisis Ekonomi dan Keuangan. Fakultas Ekonomi Universitas Indonesia.

Pusat_Data_dan_Sistem_Informasi_Pertanian. (2017). Analisis Kinerja Pedagangan Kopi (P. D. dan S. I. P. - S. J. K. Pertanian (ed.)).

Ramdhani, R. (2018). Analisis Ekspor Kopi Indonesia. Fakultas Ekonomi. Universitas Islam Indonesia.

Reyandi, D., Syaparuddin, \& Aminah, S. (2018). Ekspor Kopi Indonesia Dan FaktorFaktor Yang Mempengaruhinya. E-Jurnal Perdagangan, Industri Dan Moneter, 6(1), 23-34.

Roger, T., \& Engler, A. (2008). Risk Preferences Estimation for Small Rasberry Producers in the Bio-Bio Region Chile. Chilean Journal of Agricultural Research, 68(4), 175-182.

Setiawan, A., \& Sugiarti, T. (2016). Daya Saing dan Faktor Penentu Ekspor Kopi 
Indonesia ke Malaysia dalam Skema CEPT-AFTA. Agriekonomika, 5(2), 212-220.

Sugiyono. (2008). Metode Penelitian Kuantitatif Kualitatif dan R\&D. Alfabeta Bandung.

Sugiyono. (2017). Metode Penelitian Kombinasi (Mixed Method). Alfabeta.

Widayanti, S. M., Kiptiyah, \& Semaoen, M. I. (2009). Analisis Ekspor Kopi Indonesia. WACANA, 12(1), 192-203.

Zuhdi, F. (2016). Analisis Daya Saing Ekspor Kopi Indonesia dan Vietnam di Pasar ASEAN 5. Institut Pertanian Bogor. 